\title{
Social Work in Public Schools: Ratios of students per social worker in Portugal
}

\section{Serviço Social em Escolas Públicas: Rácios de estudantes por assistente social em Portugal}

\section{Sara Mendes $(1$ \\ Sónia Guadalupe (2)}

(1) Escola Secundária Manuel Cargaleiro, Seixal, Portugal

(2) Instituto Superior Miguel Torga, Centro de Estudos e Investigação em Saúde da Universidade de Coimbra, Coimbra, Portugal

Recebido: 18/01/2019; Revisto: 02/02/2019; Aceite: 12/02/2019.

https://doi.org/10.31211/rpics.2019.5.1.107

\begin{abstract}
Aim: This research estimates the ratio of students per social worker in public schools in Portugal. Methods: Documentary analysis was used to collect data following three steps, with specific criteria: 1) official documentary sources were first used to identify the schools that allow hiring social workers; 2) evidence was collected of their employability in the institutional webpage of each school; 3 ) a database was built, at the national and regional level for continental Portugal. Results: One hundred and twelve social workers have been identified in a universe of 811 public schools (grouped and ungrouped schools). The national ratio social worker/students in all schools of continental Portugal was 1:12.086, varying between 1:8.753 and 1:22.237. The ratio in the schools that have social worker(s) was 1:1.394, varying between 1:1.210 and 1:1.768, depending on the region. Conclusions: School social workers are very residual in the public school, highlighting alarming and unequal territorial ratios social worker-students. The results make clear the disinvestment in the profession and its aims in the education field. These results call on national and European organizations of social workers to recommend ratios of students per social worker, requiring a major investment in this crucial area of social intervention.
\end{abstract}

Keywords: Social Worker; School Social Work; Ratio; Public schools.

\section{DI\&D | ISMT}

rpics@ismt.pt

https://rpics.ismt.pt
Publicação em Acesso Aberto

(C)2019. O(s) Autor(es). Este é um artigo de acesso aberto distribuído sob a Licença Creative Commons Attribution, que permite uso, distribuição e reprodução sem restrições em qualquer meio, desde que o trabalho original seja devidamente citado.
Sara Mendes

Rua Bento de Moura Portugal 4

2845-151 Amora, Portugal

Tel.: 212269790

e-mail: sararelva@gmail.com 


\section{Resumo}

Objetivo: O presente estudo estima o rácio de estudantes por assistente social nas escolas públicas de Portugal. Métodos: A análise documental foi utilizada para a recolha de dados, seguindo três etapas com critérios específicos: 1) partimos de fontes documentais oficiais para identificar as escolas que permitem a contratação de assistentes sociais; 2) foram recolhidas evidências de empregabilidade de assistentes sociais na página institucional de cada escola; 3 ) foi construída uma base de dados, a nível nacional e regional, para o território continental de Portugal. Resultados: Foram identificados 112 assistentes sociais no universo de 811 escolas públicas (escolas agrupadas e não agrupadas). O rácio a nível nacional de assistente social/estudantes em todas as escolas de Portugal continental foi de 1:12.086, variando entre 1:8.753 e 1:22.237. O rácio nas escolas que têm assistentes sociais foi de 1:1.394, variando entre 1:1.210 e 1:1.768, dependendo da região do país. Conclusões: Os assistentes sociais são profissionais muito residuais na escola pública, destacando-se os rácios alarmantes e desiguais territorialmente de assistentes sociais/estudantes. Tal evidencia o desinvestimento na profissão e nos seus objetivos no campo da educação. Estes resultados interpelam as organizações nacionais e europeias de assistentes sociais a definir recomendações de rácios de estudantes por assistente social, exigindo um maior investimento nesta área crucial de intervenção social.

Palavras-Chave: Assistente Social; Serviço Social na Escola; Rácio; Escolas Públicas.

\section{Introduction}

Schools are institutions that promote the social and human development of children and young people (Constable, 2015), being a very complex context where all the problems of contemporary society arise. It is also a privileged field, where social workers intervene in favor of social justice through preventive actions of social risk, prevention of school failure, truancy or drop-out, and through actions to remove barriers and inequalities and to promote citizenship and equal rights and opportunities in education, as well as to ensure social protection and the development of safe and inclusive school communities.

School social work is well established in many countries in the world and is being expanded to others (Huxtable, 2013), dealing with an enormous variety of complex social problems that represent barriers to education or negatively impact school performance. For this reason, Constable (2015, p. 5) states that "their roles can be as complex as the worlds they deal with." In a multilevel systems and multitier approach to practice, the focus of the school social worker is the student-teacher-school-familycommunity system, in order to reach education inclusive mission and mandates, working on solving the problems that interfere with education, and to enhance the potential and the development of each system component (Australian Association of Social Workers [AASW], 2015; Constable, 2015; Huxtable, 2013; National Association of Social Workers [NASW], 2012; Openshaw, 2007).

The evidence shows a positive impact of school social work on education goals and on student academic performance and achievement (Alvarez, Bye, Bryant, \& Mumm, 2013; Jonson-Reid, Kontak, Citerman, Essma, \& Fezzi, 2004; Newsome, Anderson-Butcher, Fink, Hall, \& Huffer, 2008; Pritchard \& Williams, 2001), which reinforces social workers' practice wisdom (Sherman, 2016). Alvarez and colleagues (2013) analyzed school social work outcomes in the USA and found evidence that supports that the number of school social workers is a predictor of high school completion, even when poverty rates are controlled. School climate is also influenced by the integration of social workers in schools (Anderson, Thomas, Moore, \& Kool, 2008).

School social work was mainly introduced "at the end of the nineteenth and the beginning of the twentieth century as part of the universal education movement" (Huxtable, 2013, p. 5), estimated to be 
a consolidated reality in about 50 countries worldwide (Huxtable, 2013; International Network for School Social Work, 2017). In Portugal and some other European countries, such institutionalization dates back to the 1970s (Huxtable, 2013); however, the 1990s marked the development of programs and policy measures to combat persistent absenteeism and school failure, and to promote mandatory schooling (Dias \& Tomása, 2012), bringing greater relevance to school social work.

\section{School Social Work and Social Policies in Portugal}

In Portugal, the professional activity of social workers in schools was formalized in 1971 through the School Social Action Institute, whose main purpose was to provide economic support to student (Santos, 2004; Semblano, 2003). After the carnation revolution in 1974 (the revolution that overthrew the dictatorial regime that existed since 1933 in Portugal and which implemented the democratic regime), education is democratized, making basic education universal, compulsory and free, contributing to equal opportunities. However, the Education System Fundamental Law was approved nearly a decade after the transition to democracy, establishing the equity of assessing and of success as main principles in schools (Dias \& Tomása, 2012). Social workers were later integrated into the Centers of Pedagogical Medicine, afterward designated as Service of Psychology and Guidance (Semblano, 2003), that initially integrated, by law, social workers in the team constitution. However, these services were mainly composed of psychologists, and the integration of social workers was marginal (Branco, 2009), remaining almost invisible in the educational field (Santos, 2004).

"School social work is a complex and specialized field of practice that is affected by changes in education policy, research, and practice models" (NASW, 2012, p. 1), and education paradigms (Sherman, 2016). Therefore, a variety of models are used: social work can be an integral part of the school staff and multidisciplinary school team; or social workers can work in the context of a collaboration between youth welfare agencies or nongovernmental organizations and the school system (Huxtable, 2013). The first modality prevails in Portugal, and the integration of social workers depends mainly on social policies.

Currently the school programs that promote educational success in Portugal, that allow the integration of social workers in the school context, are as follows (identified by the Portuguese original acronyms): Educational Territories of Priority Intervention Program (TEIP); Integrated Program of Education and Training (PIEF); Autonomy Contracts (CA); National Program for School Success Promotion (PNPSE).

Schools select and hire human resources based on the needs determined in their school and socioeconomic context, often integrating social workers, psychologists, social educators, mediators, sociocultural animators, speech therapists, among others.

TEIP was created in 1996 (and reformulated in 2008 and 2012), following Priority Schools program started in 1988, with the aim of creating conditions for the universalization of quality education and promoting educational success, focusing on children and youth at risk of social and school exclusion (Despacho n. ${ }^{\circ}$ 147-B/ME/96, 1996), constituting a policy of positive discrimination of schools located in socially disadvantaged communities. Nowadays, this program is implemented in 137 school groups in continental Portugal (Direção-Geral da Educação [DGE], 2017).

PIEF is another program that follows a set of measures to combat child labor, in order to educational reintegrating of children and young people. PIEF aims to favor conditions for compliance with compulsory schooling, prioritizing entry into the labor market through an individualized education and 
training plan, requiring a social diagnosis and monitoring by professionals. In 2015/2016 there were 156 PIEF classes distributed by 95 schools nationwide (DGE, 2017).

The CA, which are possible since 1998, aim involving the educational community as a promoter of educational quality. Legislative changes in 2012 and 2015 favor an increase of CA, currently there are 212 schools, 46 of which are also TEIP schools. Having among its principles the promotion of equity, citizenship, inclusion and local development, favoring better school results and reducing the risk of dropping out of school, some CA have social workers.

Finally, PNPSE is a recent territorial-based program, centered on local solutions and resources to respond to the needs identified by local stakeholders. PNPSE focuses on preventive intervention against risk indicators such as abandonment, absenteeism, and school failure as well as the definition of an adequate life project in the transition to adult life. Human resources are not specified, being allocated teachers for the functions and, in some cases, psychologists; social workers are very residual (Direção-Geral da Administração Escolar, 2017).

\section{Educational challenges in Portugal in the European Union context}

Portugal has seen improvements in education indicators at several levels. It was one of the southern European countries were early leaving from school decreased between 2008 and 2016 (from $34.9 \%$ to 14\%), although it remains over the EU 2020 target of 10\% (Eurostat, 2018).

Portugal is enlarging early childhood education (from $41,7 \%$ to $88,4 \%$ in $1990 / 2016$ ), which is one of the Europe 2020 headline targets that potentially can bring future wide-ranging social and economic benefits, addressing social inclusion. As well, the schooling rate of secondary education (10 to 12th grade) increased from 28,2\% to 75,3\% (1990/2016), although it represents half of the proportion of EU average rates in population (PT 23,7\% vs. EU28 46,1\%, in 2017), having doubled the number of students in universities, in the same period, though remaining well below average in the EU (PT 24,1\% vs. EU28 31,2\%, in 2017) (Eurostat, 2018; Pordata, 2017).

Despite the favorable trajectory, there is much to be done to improve indicators of social and educational development in the different levels of education, in which school social work can play a relevant role. Thus, the present study aims to determine student ratios by the social worker in schools in Portugal, in order to contribute to the reflection about the conditions of the intervention of these professionals in the complex field of education.

\section{Methods}

We used a documentary analysis to collect data. Official data were initially requested to the governmental entities (DGAE and DGEstE from Ministry of Education of Portugal); however, it was not possible to obtain it because it proved to be impossible the identification of the number of specialized professionals in schools, separately by profession. Therefore, we opted for the systematic data collection in the institutional website of each school (considered grouped and non-grouped schools), based on an official document with the list of schools in Portugal (excluding the Autonomous Regions of Azores and Madeira). Data were collected between February 21 and May 5, 2017. 
The procedure consisted of 1) identifying the numbers of schools that present programs that allow hiring social workers as specialized professionals; 2) collecting evidence that supported the integration of social workers in the professional team (e.g., results of jog contest, educational projects, autonomy contracts, improvement plans, and external evaluation reports); 3) identifying the number of students per school. Considering the universe of 811 schools (Direção-Geral da Administração Escolar [DGAE], 2015; DireçãoGeral de Estatísticas da Educação e Ciência [DGEEC], 2016a), 306 were identified allowing hiring social workers (37.73\%) (Figure 1).

We used descriptive statistics (frequencies and proportions), and we calculated ratios based on the available data. The student-social worker ratio expresses in proportion the number of social workers concerning the number of students. If a ratio of 1000:1 indicates that there are 1000 students for 1 Social Worker, on its reverse (1:1000), it expresses the existence of 1 Social Worker for every 1000 students.

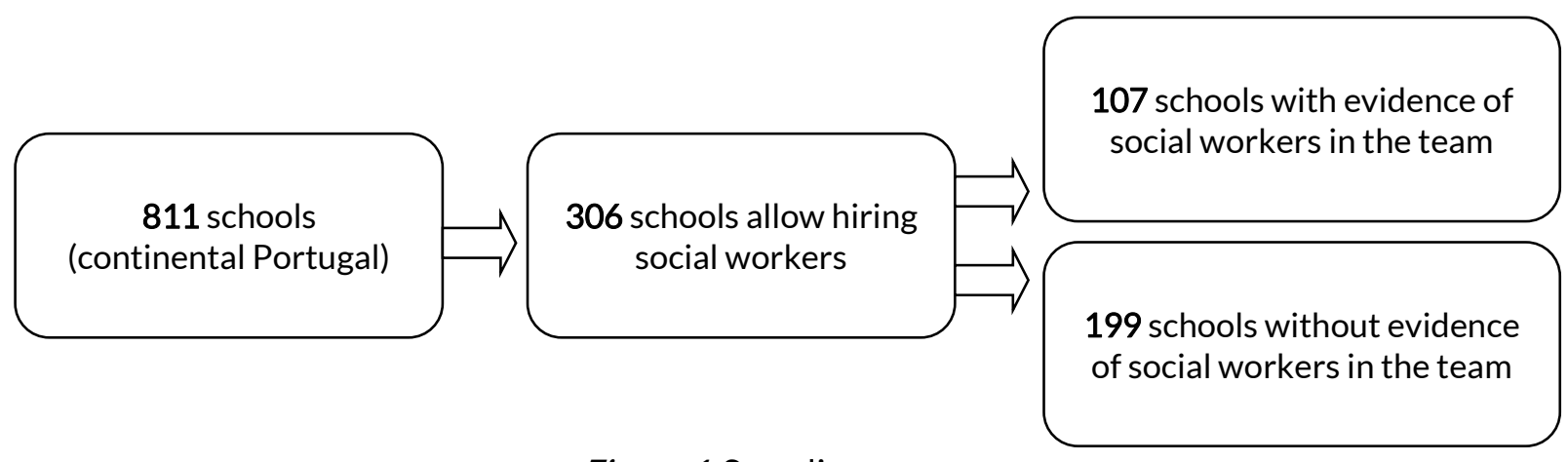

Figure 1. Sampling process.

\section{Results}

School social workers are considered within the specialized professionals, a category that includes other professions, such as psychologist, social educator, speech therapist, mediator, and cultural or social animator.

A total of 112 social workers were found in 107 schools (Table 1), that is, in $13.19 \%$ of all schools, although $37.73 \%$ allowed the hiring of Social Work specialists. The schools with TEIP and TEIP\&CA programs are those that hire a larger number of social workers, corresponding to $82 \%$ of the schools with social workers.

Regarding the distribution of social workers by region of education (Table 2), the regions with more schools (North and Lisbon) have more representativeness of these professionals. The ratios of social worker-student (Table 3) were calculated based on the number of social workers and students in schools in each region and by type of school. If we consider the number of students in continental Portugal $(1,353,590)$, we have a ratio of one social worker to more than 12,000 students. However, if we analyze it more specifically in schools that hire specialized professionals, the ratio increases to one social worker for almost 3,700 students. The ratio increases even more if we consider only the schools that have social workers: one for around 1,400 students. 
Table 1

Social Workers in Schools in Continental Portugal

\begin{tabular}{lcc}
\hline & $n$ & $\%$ \\
\hline Schools in continental Portugal & 811 & 100 \\
Schools that do not plan hiring social workers & 505 & 62.27 \\
Schools that allow hiring social workers & 306 & 37.73 \\
\hline Schools with social workers in the academic year of 2016/2017 & 107 & $13.19^{\mathrm{a}}$ \\
Social workers in schools in the academic year of 2016/2017b & 112 & $13.81^{\mathrm{a}}$ \\
\hline Schools with social workers according to special school programs ${ }^{\mathrm{c}}$ & 107 & 100 \\
TEIP & 60 & 56 \\
TEIP \& CA & 28 & 26 \\
CA & 14 & 13 \\
PNPSE & 3 & 3 \\
CA \& PNPSE & 2 & 2 \\
\hline
\end{tabular}

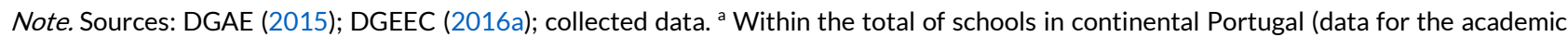
year of 2016/2017). ${ }^{\text {b }}$ There was evidence from 4 schools that hired more than one Social Worker. ${ }^{c}$ School programs that promote educational success: TEIP = Educational Territories of Priority Intervention Program; PIEF = Integrated Program of Education and Training; CA = Autonomy Contracts; PNPSE = National Program for School Success Promotion.

Table 2

Schools and Social Workers by Region in Continental Portugal

\begin{tabular}{|c|c|c|c|c|c|c|}
\hline \multirow[t]{2}{*}{ Region $^{a}$} & \multicolumn{2}{|c|}{$\begin{array}{c}\text { Schools in continental } \\
\text { Portugal }\end{array}$} & \multicolumn{2}{|c|}{$\begin{array}{c}\text { Schools TEIP/CA/ } \\
\text { PNPSE }^{\mathrm{b}} \\
\end{array}$} & \multicolumn{2}{|c|}{ Schools with Social Worker } \\
\hline & $n$ & $\%$ & $n$ & $\%$ & $n$ & $\%$ \\
\hline North & 291 & 36 & 115 & 38 & 34 & 32 \\
\hline Centre & 195 & 24 & 61 & 20 & 13 & 12 \\
\hline Lisbon Metropolitan Area & 198 & 24 & 85 & 28 & 44 & 41 \\
\hline Alentejo & 88 & 11 & 31 & 10 & 9 & 8 \\
\hline Algarve & 39 & 5 & 14 & 4 & 7 & 7 \\
\hline Total & 811 & 100 & 306 & 100 & 107 & 100 \\
\hline
\end{tabular}

Note. Sources: DGAE (2015); DGEEC (2016a); collected data. ${ }^{a}$ The Region corresponds to Nomenclature of Territorial Units for Statistics and to the DGE (Regional Board of Education). ${ }^{\mathrm{b}}$ TEIP = Educational Territories of Priority Intervention Program; PIEF = Integrated Program of Education and Training; CA = Autonomy Contracts; PNPSE = National Program for School Success Promotion.

Table 3

Ratio Social Worker-Students in Portuguese Public Schools by Region

\begin{tabular}{|c|c|c|c|}
\hline Region $^{a}$ & $\begin{array}{c}\text { Ratio for schools in Portugal } \\
\text { Continental }\end{array}$ & $\begin{array}{l}\text { Ratio for schools with } \\
\text { TEIP/CAVPNPSE }\end{array}$ & $\begin{array}{l}\text { Ratio for schools with social } \\
\text { worker }\end{array}$ \\
\hline North & 1:13.551 & $1: 4.339$ & $1: 1.397$ \\
\hline Centre & $1: 22.237$ & $1: 6.021$ & $1: 1.251$ \\
\hline Lisbon Metropolitan Area & 1:8.848 & $1: 2.642$ & $1: 1.410$ \\
\hline Alentejo & 1:10.536 & 1:3.301 & $1: 1.210$ \\
\hline Algarve & 1:8.753 & $1: 3.262$ & 1:1.768 \\
\hline Portugal (continental) & 1:12.086 & $1: 3.693$ & $1: 1.394$ \\
\hline North & 1:13.551 & $1: 4.339$ & $1: 1.397$ \\
\hline
\end{tabular}

Note. Sources: DGAE (2015); DGEEC (2016a); collected data. ${ }^{\text {a }}$ The Region corresponds to nomenclature of territorial units for statistics and to the DGE (Regional Board of Education); Source: DGEEC (2016a). ${ }^{\text {b }}$ TEIP = Educational Territories of Priority Intervention Program. $\mathrm{PIEF}=$ Integrated Program of Education and Training; $\mathrm{CA}=$ Autonomy Contracts; PNPSE = National Program for School Success Promotion. 


\section{Discussion}

The results show a very weak representation of social workers in schools in Portugal, especially when we consider the number of students. The data show that in Portugal there is one social worker for every 12,000 students.

The territorial iniquity of the distribution of social workers in schools is evident, with ratios always higher than one social worker for 8,700 students. The Centre region is the one with the lowest ratio, perhaps because it is an area where only about $30 \%$ of schools have special school programs (TEIP, CA and/or PNPSE). On the other hand, Lisbon has the highest number of school social workers and has a higher ratio. However, the North is the second region with the highest number of social workers and the second with the lowest ratios. The proportion of schools TEIP/CA/PNPSE, in the number of schools in each region, is higher in Lisbon than in the North (42.9\% vs. $39.5 \%$, respectively), which may partly explain the results, since we find more often social workers in these schools. The offer of higher education in social work is also more concentrated in Lisbon than in the North of the country, which can also influence the selection of human resources.

In the 306 schools with special school programs, the ratios change significantly, being one Social Worker for every 3,700 students. In this case, we can highlight the Centre region with a lower ratio $(1: 6,021)$, followed by the North $(1: 4,339)$ and once again, Lisbon is the region with the lowest ratio $(1: 2,642)$, although North is the region with more programs to promote educational success.

The results point to ratios that constitute a severe impediment to an adequate social intervention. In schools that have social workers, we find a ratio of one social worker per every 1,394 students (around 1,400). The analysis by region shows that it is in the Algarve that we find the lowest ratio $(1: 1,768)$, despite the representation of social workers in $50 \%$ of schools with special programs. Lisbon appears with a ratio of 1:1,410 and the North with a ratio of 1:1,397. The Central and Alentejo regions have the highest ratios (1:1,251 and 1:1,210, respectively). Between schools, the hiring criteria do not seem to be based on ratios, since we find schools with about 500 students with one social worker, but also schools with 2,000 students in which only one professional is working.

These data are representative of the low expressiveness of social workers in public schools in Portugal. In the national literature review, there is little reference to the integration of social workers in the field of education. In 1996 were integrated into the education field 131 social workers (Branco, 2009) and, specifically in one program (SPO), there were 49 social workers in 1993 and 33 in 1999 (Despacho n. 196/B/MF/ME/93, 1993; Despacho n.0 9022/99, 1999). Duarte (2016) reports data regarding schools with TEIP program, stating that in the academic year 2015/2016 there were 92.5 social workers in continental Portugal (28.5 in the North region; 4.5 in the Centre; 43.5 in Lisbon; 9 in Alentejo, and 7 in the Algarve. Thus, our results are between the 92 and the 130 identified before (Branco, 2009; Duarte, 2016). The available data shows that the integration of social workers in this area has always been scarce. This may since school social work has not been a privileged field in the social work degree, but it is more likely due to policy options in the education field. We observe that the school boards, when selecting specialized professionals, tend to privilege psychologists relative to other professionals, such as social workers, especially when they only have the budget to hire one specialized professional in full time. Probably, the school boards and the community of teachers are not yet sufficiently familiar and sensitized to the role of the social worker in the education field, not equating them as an essential human resource in schools. 
Although there are estimated data on the number of school social workers in some countries worldwide (Huxtable, 2013), at national and European level we have not identified any institutional orientations for ratios of students by social worker. However, internationally we found recommendations in the USA and Australia (from the School Social Work Association of America and the Australian Association of Social Workers) (AASW, 2015; School Social Work Association of America, 2013). SSWAA argues a ratio of 1:250 students and recommends that the number of students should decrease according to their characteristics and specificities. The AASW also supports the same principle adding that this ratio should also consider the characteristics and needs of the community, recommending a ratio of 1:500 students. Given the current reality in Portuguese schools, these ratios seem utopian. However, we argue that a change in policies should reorient priorities and to determine the constitution of multidisciplinary teams in schools, favoring a context where is possible to reach these ratios, which, in practice, would correspond to one social worker per school (or grouped schools), in general.

Regarding other professional categories, we found international recommendations of ratio psychologistsstudents of 1:1,000 (Ordem dos Psicólogos Portugueses [OPP], 2015). In Portugal, in the academic year of 2014/2015, there were 795 psychologists in public education, representing a ratio of 1:1,650 (OPP, 2015). The reality of the numbers tells us that school social workers currently represent $14 \%$ of the number of psychologists in schools in Portugal, and an increase was announced in the number of these professionals, but not of social workers.

If we consider the recommendations for ratios, according to the universe of students in public schools, it will take more 683 social workers to obtain similar ratios than the psychologists, and it would be necessary to have around 2700 or 5300 social workers to reach the ratios defended for Australia and the USA, respectively. In this regard, it is very pertinent the role of professional associations in the promotion of the "advance of school social work through advocacy, improvement of professional standards, training and development", in many countries (Huxtable, 2013, p. 9).

In the Statute of the Student and School Ethics (Lei n. ${ }^{\circ}$ 51/2012, 2012) multidisciplinary teams are planned to follow students permanently, especially those with learning difficulties, with a risk of dropping out of school and risk behavior. However, social workers appear once again as professionals diluted in the group of specialized professionals and not as permanent members of a basic team. This team would promote a qualified intervention, favoring better outcomes with social work unique knowledge (Constable, 2015; Huxtable, 2013). As it seems, school social workers, instead of being considered an invaluable resource, remain marginalized and discounted within the school ecosystem (Sherman, 2016) and within most education systems (Huxtable, 2013), being apparently deferred to other specialized professionals.

Although the universality of the public school and the schooling being compulsory until the age of 18 in Portugal, structural factors that maintain social inequalities and impediments to social mobility tend to persist (Direção-Geral de Estatísticas da Educação e Ciência, 2016b; Nogueira \& Nogueira, 2002), having in the country a child poverty risk rate of $21.5 \%$ in 2016 (Pordata, 2017). Therefore, it is urgent to look at social workers as education professionals who understand the complexity of these structural inequalities and are qualified to intervene in this demanding context. These professionals "support student's educational success, especially those who are marginalized by poverty, oppression, disability and other personal or social problems" (Huxtable, 2013, p. 1). If social workers' knowledge and skills are vital in the work to make the education mission and process effective (Alvarez et al., 2013; Constable, 2015), how 
effective can be their work with inappropriate ratios and workloads? Given that the Portuguese ratio is one social worker for every 12,086 students, we can say that social intervention does not seem to be a priority of educational policies in this country.

\section{Limitations and Future Research}

Official data of DGAE and DGEstE from the Ministry of Education of Portugal does not allow the identification, separately by profession, of the number of specialized professionals in schools, namely social workers. The alternative documentary methodology, with systematic data collection in the institutional website of each school, is much more limited, not allowing us the same certainty about data. However, systematic collection, based on documentary criteria, following an official list of schools, ensures the reliability of the data. Thus, this study presents as the main limitation only to be able to determine the estimated data, given the unofficial nature of data regarding the number and distribution of social workers per schools. Therefore, results have generalization limitations.

Future research should address the workloads and the burden associated with the ratios between professionals and students, as well as to deepen the analysis of relevant social indicators (e.g., school failure, truancy, drop-out, social risk, inequalities, and poverty risk) according with the (in)existence of social workers in the schools and these ratios.

\section{Conclusion}

Evidence shows that in Portugal, School Social Work is far from being a consolidated professional area. Despite the implementation of various educational policies emphasizing domains and aims historically associated with the specific action of social workers, these have not yet been affirmed as an indispensable human resource in this area. Social work responds plurally to a context of enormous complexity with all kinds of problems of contemporary society. The lack of adequate and specialized human resources in schools has been a risk assumed by public policies that deserve to be denounced by evidence.

The educational policies and programs that promote school success or combat dropout, absenteeism and school failure that have been implemented have not required a structured intervention in a multidisciplinary team that includes the social worker as an essential professional whose intervention is crucial for the achievement of such goals. As a professional category, social workers need a collective reflection on the intervention constraints and the operational limitations that the excessively unbalanced ratios of students by social worker put to the realization of a socio-political project based on the promotion of equal opportunities and to fight against social injustice from the context of education.

The recommendation of ratios by international organizations of the profession would ensure the support and reinforcement of such claims at the national level. It is, therefore, urgent to define ratios studentsocial worker in schools for European countries, considering their characteristics and differences, to overcome this severe gap.

Conflito de interesses | Conflict of interest: nenhum | none.

Fontes de financiamento | Funding sources: nenhuma | none.

Contributos | Contributions: SM: Revisão da literatura; recolha, inserção e tratamento dos dados; redação do manuscrito.

SG: Contributo na redação do manuscrito; discussão dos dados; revisão da redação final do manuscrito. 


\section{References}

Alvarez, M. E., Bye, L., Bryant, R., \& Mumm, A. M. (2013). School social workers and educational outcomes. Children \& Schools, 35(4), 235-243. https://doi.org/10.1093/cs/cdt019

Anderson, A., Thomas, D. R., Moore, D. W., \& Kool, B. (2008). Improvements in school climate associated with enhanced health and welfare services for students. Learning Environments Research, 11(3), 245-256. https://doi.org/10.1007/s10984-008-9044-5

Australian Association of Social Workers. (2015). Scope of social work practice: School social work. Melbourne: AASW. Retrieved from https://www.aasw.asn.au/document/item/8308

Branco, F. (2009). A profissão de assistente social em Portugal [The profession of social worker in Portugal]. Locus Social, 3, 61-89. Retrieved from http://cesss.fch.lisboa.ucp.pt/images/site/locus-social/locus-socialn3-2009.pdf\#page $=55 \& z o o m=80$

Constable, R. (2015). The role of the school social worker. In C. R. Massat, M. S. Kelly, \& R. Constable (Eds.), School social work - practice, policy, and research (8 ${ }^{\text {th }}$ ed., pp. 3-24). Oxford: Oxford University Press.

Despacho n. ${ }^{\circ}$ 147-B/ME/96 de 1 de agosto. Diário da República n. ${ }^{\circ} 177 / 1996$, Série // [Portuguese legislation]. Lisboa: Ministério da Educação. Retrieved from https://dre.pt/web/guest/pesquisa//search/1863460/details/maximized?tipo_facet=Despacho\&fqs=n. ${ }^{\circ} 20177 \% 2 F 1996 \&$ perPage $=25 \& q=n .{ }^{\circ}$ \%20177\%2F1996

Despacho n. ${ }^{\circ}$ 196/B/MF/ME/93 de 2 de novembro. Diário da República n. ${ }^{\circ}$ 256/1993, $1 .^{\circ}$ Suplemento, Série // [Portuguese legislation]. Lisboa: Ministério das Finanças. Retrieved from https://dre.pt/web/guest/pesquisa/-/search/1030313/details/normal?q=196\%2FB\%2FMF\%2FME\%2F93

Despacho n. ${ }^{\circ}$ 9022/99 de 6 de maio. Diário da República n. ${ }^{\circ}$ 105/1999, Série //[Portuguese legislation]. Lisboa: Ministério da Educação - Secretário de Estado da Administração Educativa. Retrieved from https://dre.pt/web/guest/pesquisa/-/search/936357/details/normal?q=Despacho+n. ${ }^{0} \% 209022 \% 2 F 99$

Dias, M., \& Tomása, C. (2012). Education and equity in semi-peripheral countries: Current trends in the field of priority education in Portugal. Procedia - Social and Behavioral Sciences, 47, 1092-1096. https://doi.org/10.1016/j.sbspro.2012.06.784

Direção-Geral da Administração Escolar. (2015). Códigos de agrupamentos e escolas não agrupadas [Grouping codes and non-grouped schools]. Lisboa: DGAE, Ministério da Educação. Retrieved from http://www.dgae.mec.pt/?wpfb_dl=23011

Direção-Geral da Administração Escolar. (2017). Sistema interativo de gestão de recursos humanos da educação [Interactive human resources management system for education]. Lisboa: DGAE, Ministério da Educação. Available from https://sigrhe.dgae.mec.pt/openerp/login

Direção-Geral da Educação. (2017). Medidas de promoção do sucesso educativo [Measures to promote educational success]. Lisboa: DGE, Ministério da Educação. Retrieved from http://www.dge.mec.pt/medidas-de-promocao-do-sucesso-educativo

Direção-Geral de Estatísticas da Educação e Ciência. (2016a). Regiões em números 2014/2015 - Retrato geral [Regions in numbers 2014/2015 - General portrait]. Lisboa: DGEEC, Ministério da Educação. Retrieved from http://www.dgeec.mec.pt/np4/96/

Direção-Geral de Estatísticas da Educação e Ciência. (2016b). Desigualdades socioeconómicas e resultados escolares - 3. ${ }^{\circ}$ Ciclo do Ensino Público Geral[Socioeconomic inequalities and school outcomes - 3rd Cycle of General Public Education]. Lisboa: DGEEC, Ministério da Educação. Retrieved from http://www.dgeec.mec.pt/np4/97/

\%7B \$clientServletPath\%7D/?newsld=147\&fileName=DesigualdadesResultadosEscolares.pdf

Duarte, M. (2016). Projetos educativos em escolas públicas no âmbito da escolaridade obrigatória: O serviço social nos programas TEIP e PIEF [Educational projects in public schools in the scope of compulsory schooling: The social service in the TEIP and PIEF programs] (Master's thesis, Instituto Superior Miguel Torga, Coimbra). Retrieved from http://repositorio.ismt.pt/handle/123456789/701 
Eurostat. (2018). Europe 2020 indicators - education. Retrieved from http://ec.europa.eu/eurostat/statisticsexplained/index.php/Europe_2020_indicators___education

Huxtable, M. (2013). A global picture of school social work in 2013. Port Townsend, Washington: INSSW. Retrieved from https://www.pravo.unizg.hr/_download/repository/A_Global_Picture_of_School_Social_Work_in_2013.pdf

International Network for School Social Work. (2017). International network for school social work. Retrieved from http://internationalnetwork-schoolsocialwork.htmlplanet.com/International\%20Network/Index.html

Jonson-Reid, M., Kontak, D., Citerman, B., Essma, A., \& Fezzi, N. (2004). School social work case characteristics, services, and dispositions: Year one results. Children \& Schools, 26(1), 5-22. https://doi.org/10.1093/cs/26.1.5

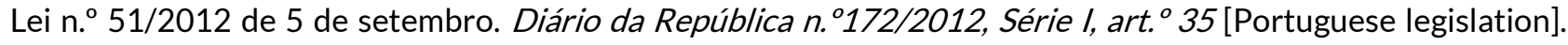
Lisboa: Assembleia da República. Retrieved from https://data.dre.pt/eli/lei/51/2012/09/05/p/dre/pt/html

National Association of Social Workers. (2012). NAWS standards for school social work services. Washington, DC: NASW. $\quad$ Retrieved from https://nyssswa.org/wpcontent/uploads/2017/09/naswschoolsocialworkstandards-2012.pdf

Newsome, W. S., Anderson-Butcher, D., Fink, J., Hall, L., \& Huffer, J. (2008). The impact of school social work services on student absenteeism and risk factors related to school truancy. School Social Work Journal, 32(2), 21-38. Retrieved from https://www.researchgate.net/publication/234561237_The_Impact_of_School_Social_Work_Services_on_S tudent_Absenteeism_and_Risk_Factors_Related_to_School_Truancy

Nogueira, C. M. M., \& Nogueira, M. A. (2002). A sociologia da educação de Pierre Bourdieu: Limites e contribuições [The sociology of education of Pierre Bourdieu: Limits and contributions]. Educação \& Sociedade, 78, 15-36. Retrieved from http://www.scielo.br/pdf/es/v23n78/a03v2378

Openshaw, L. (2007). Social work in schools: Principles and practice. New York, NY: Guilford Press.

Ordem dos Psicólogos Portugueses. (2015). OPP defende reforço da psicologia no sistema público de Ensino [OPP defends reinforcement of psychology in the public system of Education]. Lisboa: OPP. Retrieved from https://www.ordemdospsicologos.pt/pt/noticia/1496

Pordata. (2017). PORDATA - Estatísticas, gráficos e indicadores de Municípios, Portugal e Europa [Statistics]. Lisboa: Fundação Francisco Manuel dos Santos. Retrieved from http://www.pordata.pt

Pritchard, C., \& Williams, R. (2001). A three-year comparative longitudinal study of a school-based social work family service to reduce truancy, delinquency and school exclusions. Journal of Social Welfare and Family Law, 23(1), 23-43. https://doi.org/10.1080/09649060010012255

Santos, S. (2004). O serviço social e o seu significado nos serviços de psicologia e orientação do Ministério da Educação: Análise da década de 90 [Social work and its meaning in the services of psychology and guidance of the Ministry of Education: Analysis of the 1990s] (Master's thesis, Instituto Superior Miguel Torga, Coimbra). Retrieved from http://repositorio.ismt.pt/handle/123456789/166

School Social Work Association of America. (2013). School social workers helping students succeed: Recommended school social worker to student ratios. London, UK: SSWAA.

Semblano, M. I. B. A. (2003). Serviço social escolar em Portugal - Trajectórias e dinâmicas nos anos 60 e 70 [School social work in Portugal - Trajectories and dynamics in the 60s and 70s] (Master's thesis, Instituto Superior Miguel Torga, Coimbra). Retrieved from http://repositorio.ismt.pt/handle/123456789/165

Sherman, M. C. (2016). The school social worker: A marginalized commodity within the school ecosystem. Children \& Schools, 38(3), 147-151. https://doi.org/10.1093/cs/cdw016 